УДК 656.025.2

\title{
FUZZY PRODUCTION MODEL OF URBAN PUBLIC PASSENGER TRANSPORT SUSTAINABLE DEVELOPMENT
}

\author{
V. Vdovychenko, Assoc. Prof., PhD., \\ Kharkiv National Automobile and Highway University
}

\begin{abstract}
The structure of unclear production model of steady development of urban public passenger transport, which is based on the selection of risk factors, estimation of the character of its multilevel connections within the limits of a single transport space, has been worked out. The fuzzy production rules of forming the risks of constancy are presented from the perspective of influence on the municipal environment.
\end{abstract}

Key words: public passenger transport, risk, steady development.

\section{НЕЧЕТКАЯ ПРОДУКЦИОННАЯ МОДЕЛЬ УСТОЙЧИВОГО РАЗВИТИЯ ГОРОДСКОГО ОБЩЕСТВЕННОГО ПАССАЖИРСКОГО ТРАНСПОРТА}

\author{
В.А. Вдовиченко, доц., к.т.н., \\ Харьковский национальный автомобильно-дорожный университет
}

\begin{abstract}
Аннотация. Предложено на основе разработанных нечетких продукционных правил в пределах выделенной многоуровневой формы представления функций городского общественного пассажсирского транспорта рассматривать прочесс формирования устойчивого развития городской среды через оценку рисков возникновения критических состояний его транспортнофункииональных субъектов.
\end{abstract}

Ключевые слова: городской пассажирский транспорт, риск, устойчивое развитие.

\section{НЕЧІТКА ПРОДУКЦЙНА МОДЕЛЬ СТАЛОГО РОЗВИТКУ МІСЬКОГО ГРОМАДСЬКОГО ПАСАЖИРСЬКОГО ТРАНСПОРТУ}

\author{
В.О. Вдовиченко, доц., к.т.н., \\ Харківський національний автомобільно-дорожній університет
}

Анотація. Запропоновано на основі розроблених нечітких продукційних правил у межах виділеної багаторівневої форми подання функиій міського громадського пасажирського транспорту розглядати прочес формування сталого розвитку міського середовища через оцінку ризиків виникнення критичних станів його транспортно-функиіональних суб'єктів.

Ключові слова: міський пасажирський транспорт, ризик, сталий розвиток.

\section{Introduction}

The urban public passenger transport (UPPT) is a major component part of the territorial structure of economy and it considerably influences the socio-economic and materially-spatial development of cities. The problem of improving the efficiency of UPPT operation presents an important economic value and does not only relate to technical and economic aspects but equally influences the social terms of develop- ment of the municipal environment (ME). The conditions of effective modern UPPT operation provide a high level of transport service quality at the sound use of resources and limitation of their negative influence on the ME. The problem of providing permanent UPPT acquires a wide interest and requires the selection of forms of its presentation, development of modern methods and approaches of its formation, creation of methodologies for estimating its efficiency and the mechanisms for its improvement. 


\section{Analysis of Publications}

Recently, the task of estimating the level of constancy of the public passenger transport and the search of ways for its improvement has acquired considerable attention at forming strategic tasks of urban development [1]. The current approaches to forming the evaluation indicators of passenger transport steady development are used for making a general comparison of territorial structures (countries, cities, regions) as well as to form their rating [2]. Alternatively, their aim is an estimation of dynamics, for this purpose the change of indicators is investigated in the course of the years. In addition, the aim is to determine the degree of achievement of special purpose indexes that can be examined both as standard or threshold ones [3]. In this case it is necessary to work out a system of indexes and confirm their values that will become a guideline for the estimation.

The development of indicators and indexes of sustainable mobility, which are in the focus of modern researches, is a task that has not acquired a clear unambiguous format so far. Currently, the Organisation for Economic Cooperation and Development, the European Commission, the World Bank, the Eurostat, the European Environmental Agency and others are developing independent systems of indicators. In addition to the authorities, the problem of allocation of appropriate forms of urban transport system sustainability assessment is reflected in modern scientific works [4-7].

The establishment of a spectrum of transport sustainability assessment is implemented by creating sets of indicators that can be allocated to the relevant assessment groups:

- the causal relationships that lead to the positive or negative influence on the formation of transport sustainability;

- estimation of the change in the state of social, economic and ecological environment;

- determination of the level of influence and control of the factors which determine the regularity of transport.

Regardless of the nature of representation of the structure of indicators of sustainability, a major disadvantage of existing approaches is their focus on the evaluation of the effective parameters. In the face of uncertainty and significant external impacts evaluation of complex functional processes on the basis of effective param- eters does not allow providing an objective presentation of clear limits of their value. Such conditions make it possible to prove the necessity of introducing the new forms of UPPT permanence representation from the position of estimating the level of criticality of their parameters in relation to internal and external subjects.

\section{Purpose and Tasks}

The aim of the work is forming the structure of fuzzy productional model of steady development of UPPT. For the achievement of the put aim it is necessary to solve next tasks:

- to distinguish the factors of risks of constancy of UPPT;

- to work out the fuzzy productional rules of forming of estimation of risks of constancy of UPPT.

\section{Development of a Risk-System for Assessing the Sustainability of UPPT}

Analysis of the consistency, completeness and interdependence of the UPPT stability risks consists in consideration of the whole risk system, the unity of which is ensured through interconnection and interaction in the process of its functioning. The functional processes that occur in the objects of subsystems of UPPT maintenance and provision and external systems ME is considered as the link which should conform to the principles of self-organization and unity of management. Risks in this system are identified with internal fluctuations that take the system out of balance. The magnitude of the output determines the amount of their assessment, and rebalancing determines the impact methods. The complexity of formalization of the consistency of risk assessment lies in the fuzziness of their submission and the hierarchy of inter-level influence. To assess the stability risks of UPPT in terms of the meta-system of ME it is possible to use the fuzzy productional model, which basically involves a network that allows actualizing various components of fuzzy models and the possibility of fuzzy inference formalization. The characteristic of risk factors is presented in table 1.

The construction of a fuzzy production network includes determining the plurality $n$ of the risk factors $U=\left\{u_{i}\right\}, i=\overline{1, n}$ and the plurality $m$ of risk indicators. Certain pluralities are included into the corresponding methodological levels of UPPT presentation and characterize its risksystem from the positions of ME. 
Table 1 Risk factors of UPPT sustainability

\begin{tabular}{|c|c|}
\hline Type & The name of the linguistic variable \\
\hline \multicolumn{2}{|r|}{ Level 1 - the route network of UPPT } \\
\hline $\mathrm{u}_{11}$ & $\begin{array}{l}\text { Exceeding of demand above the sugges- } \\
\text { tion }\end{array}$ \\
\hline $\mathrm{u}_{12}$ & $\begin{array}{l}\text { Lack of internal resources of UPPT en- } \\
\text { terprises }\end{array}$ \\
\hline $\mathrm{u}_{13}$ & $\begin{array}{l}\text { Physical and mental aging of transport } \\
\text { vehicles }\end{array}$ \\
\hline $\mathrm{u}_{14}$ & $\begin{array}{l}\text { Technical failures in the process of vehi- } \\
\text { cles operation }\end{array}$ \\
\hline $\mathrm{u}_{15}$ & High innitial price of transportations \\
\hline $\mathrm{u}_{16}$ & $\begin{array}{l}\text { Complication of terms of technological } \\
\text { operations implementation }\end{array}$ \\
\hline \multicolumn{2}{|r|}{ Level 2 - the system of UPPT } \\
\hline $\mathrm{u}_{21}$ & $\begin{array}{l}\text { The decline in the quality of transport } \\
\text { service of passengers }\end{array}$ \\
\hline $\mathrm{u}_{22}$ & Refuse of service \\
\hline $\mathrm{u}_{23}$ & $\begin{array}{l}\text { Violation of the operating modes of vehi- } \\
\text { cles }\end{array}$ \\
\hline $\mathrm{u}_{24}$ & $\begin{array}{l}\text { Decrease in the carrying capacity of } \\
\text { UPPT }\end{array}$ \\
\hline $\mathrm{u}_{25}$ & Reduced cost of transportation \\
\hline $\mathrm{u}_{26}$ & $\begin{array}{l}\text { The selection of individual elements of } \\
\text { the transport infrastructure for UPPT }\end{array}$ \\
\hline $\mathrm{u}_{27}$ & $\begin{array}{l}\text { The use of additional resources of UPPT } \\
\text { enterprises }\end{array}$ \\
\hline $\mathrm{u}_{28}$ & $\begin{array}{l}\text { The limited traffic capacity of the objects } \\
\text { of passenger transportation infrastructure }\end{array}$ \\
\hline $\mathrm{u}_{29}$ & $\begin{array}{l}\text { Discoordination of the interaction of } \\
\text { UPPT elements }\end{array}$ \\
\hline \multicolumn{2}{|r|}{ Level 3 - the municipal transport system } \\
\hline $\mathrm{u}_{31}$ & Decline of the level of transport service \\
\hline $\mathrm{u}_{32}$ & $\begin{array}{l}\text { Increasing the impact of transport on the } \\
\text { environment }\end{array}$ \\
\hline $\mathrm{u}_{33}$ & $\begin{array}{l}\text { Decrease in the level of transport organi- } \\
\text { zation }\end{array}$ \\
\hline $\mathrm{u}_{34}$ & Appearance of emergency situations \\
\hline $\mathrm{u}_{35}$ & $\begin{array}{l}\text { The growth of the economic effects of } \\
\text { the transport }\end{array}$ \\
\hline $\mathrm{u}_{36}$ & $\begin{array}{l}\text { The necessity of constructing new objects } \\
\text { of transport infrastructure }\end{array}$ \\
\hline \multicolumn{2}{|r|}{ Level 4 - meta-system } \\
\hline $\mathrm{u}_{41}$ & Social tension \\
\hline $\mathrm{u}_{42}$ & $\begin{array}{l}\text { The capacity constraints of the urban } \\
\text { environment }\end{array}$ \\
\hline $\mathrm{u}_{43}$ & $\begin{array}{l}\text { Destabilization of the economic envi- } \\
\text { ronment }\end{array}$ \\
\hline $\mathrm{u}_{44}$ & $\begin{array}{l}\text { The uselessness of municipal territories } \\
\text { for residence }\end{array}$ \\
\hline \multicolumn{2}{|r|}{ General level } \\
\hline $\mathrm{u}_{5}$ & Po \\
\hline
\end{tabular}

In the conditions of multilevel presentation of the risk-system there are transitions from risk factors to their indexes. Connection is implemented on the basis of MISO principles - structure (many entrances - one exit) and presents a cascade combination of fuzzy productional rules that implement a mapping of the input factors on the overall risk. The structure of the multilevel fuzzy production network of the risk assessment model of UPPT sustainability is shown in Fig. 1.

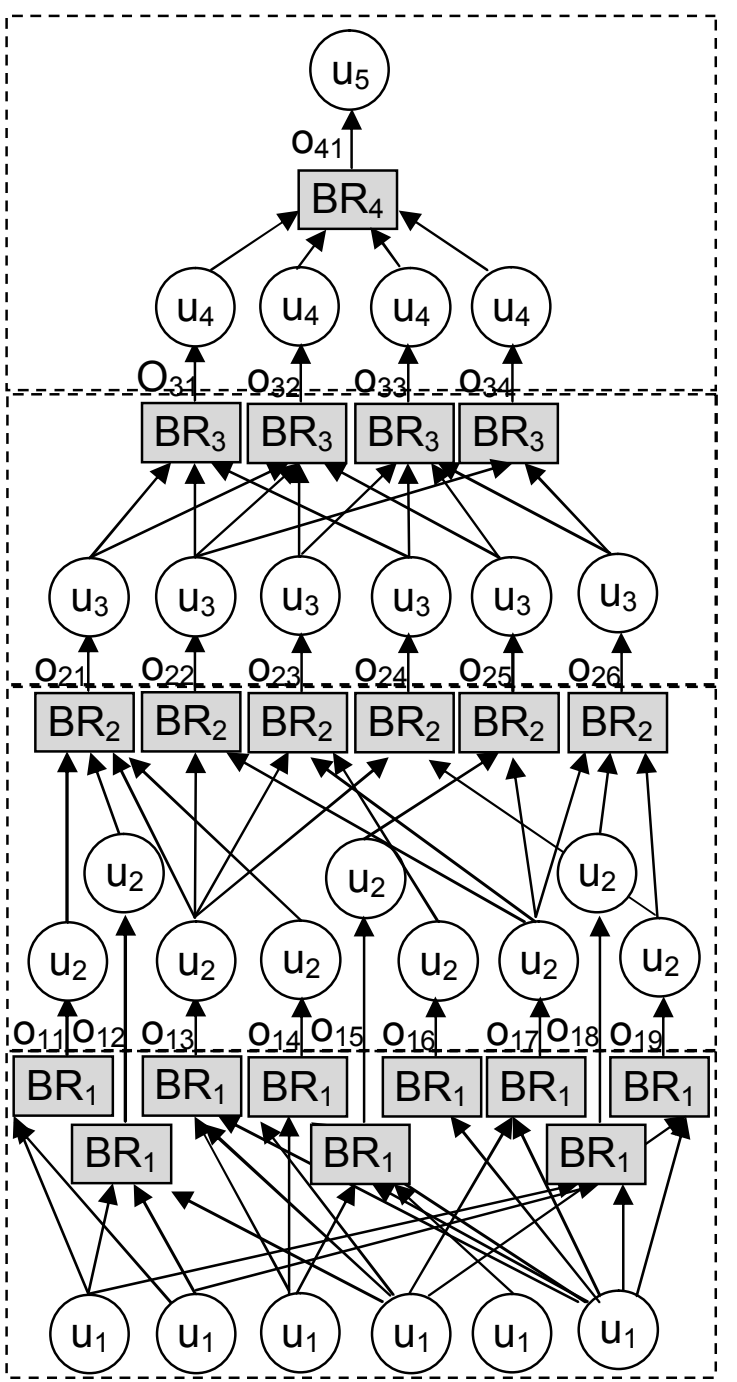

Fig. 1. The multilevel fuzzy production network of the risk assessment model of UPPT sustainability

The estimation of the level of parameters of the risk system is conducted by means of linguistic variables that can be presented as great numbers of terms. The terms are presented by three variants, for risk factors: $L-$ is low accordance, $P$ is partial accordance and $C$ - is complete accordance. The selection of risk factors and their indexes is conducted on the basis of analysis of the structure of internal and external UPPT connections within the limits of ME. The estimation of risk indexes is conducted by means of three terms: $L E R$ - low expectation of risk, MER the middle level of risk expectation and HER is the high expectation of risk, CER - the critical condition of the expected risk that according to their value correspond to the terms of risk of a higher level of UPPT presentation. 
To form the estimations and fuzzy productional rules of a model they use analytical forms of presentation of intercommunications of the UPPT risk model. For each methodological level they develop their own database of BR rules that define the status of risk indicators based on the analysis of factors and risk indicators. Fuzzy production rules are divided into two groups. The first group reflects the acceptable level of the risk value at which the level of negative exposure does not exceed the average level and

Table 2 Fuzzy production rules of forming of risk assessment of sustainability of UPPT

\begin{tabular}{|c|c|c|c|c|c|}
\hline \multirow[t]{2}{*}{ Base } & \multirow[t]{2}{*}{ Risk } & \multicolumn{4}{|c|}{ The indicator of risk } \\
\hline & & LER & MER & HER & CER \\
\hline \multicolumn{6}{|c|}{ Level 1 - the route network of UPPT } \\
\hline $\mathrm{BR}_{11}$ & $\mathrm{o}_{11}$ & $\mathrm{u}_{11}=\mathrm{Lu}_{12}=\mathrm{P}$ & $\mathrm{u}_{11}=\mathrm{Pu}_{12}=\mathrm{P}$ & $\mathrm{u}_{11}=\mathrm{Cu}_{12}=\mathrm{P}$ & $\mathrm{u}_{11}=\mathrm{Cu}_{12}=\mathrm{C}$ \\
\hline $\mathrm{BR}_{12}$ & $\mathrm{O}_{12}$ & $\mathrm{u}_{11}=\mathrm{Lu}_{12}=\mathrm{Pu}_{14}=\mathrm{L}$ & $\mathrm{u}_{11}=\mathrm{P}\left(\mathrm{u}_{12}=\mathrm{Pu}_{14}=\mathrm{P}\right)$ & $\mathrm{u}_{11}=\mathrm{Cu}_{12}=\mathrm{Pu}_{14}=\mathrm{P}$ & $\mathrm{u}_{11}=\mathrm{Cu}_{12}=\mathrm{Cu}_{14}=\mathrm{C}$ \\
\hline $\mathrm{BR}_{13}$ & $\mathrm{O}_{13}$ & $\mathrm{u}_{13}=\mathrm{Pu}_{14}=\mathrm{Lu}_{16}=\mathrm{L}$ & $\mathrm{u}_{13}=\mathrm{Pu}_{14}=\mathrm{Pu}_{16}=\mathrm{L}$ & $\begin{array}{c}\mathrm{u}_{13}=\mathrm{C}\left(\mathrm{u}_{14}=\mathrm{Cu}_{16}=\right. \\
=\mathrm{C})\end{array}$ & $\mathrm{u}_{13}=\mathrm{Cu}_{14}=\mathrm{Cu}_{16}=\mathrm{C}$ \\
\hline $\mathrm{BR}_{14}$ & $\mathrm{O}_{14}$ & $\mathrm{u}_{13}=\mathrm{Pu}_{14}=\mathrm{Lu}_{16}=\mathrm{L}$ & $\mathrm{u}_{13}=\mathrm{Cu}_{14}=\mathrm{Pu}_{16}=\mathrm{L}$ & $\begin{array}{c}\left(\mathrm{u}_{13}=\mathrm{Cu}_{14}=\mathrm{C}\right) \mathrm{u}_{16}= \\
=\mathrm{C}\end{array}$ & $\mathrm{u}_{13}=\mathrm{Cu}_{14}=\mathrm{Cu}_{16}=\mathrm{C}$ \\
\hline $\mathrm{BR}_{15}$ & $\mathrm{O}_{15}$ & $\mathrm{u}_{13}=\mathrm{Lu}_{15}=\mathrm{Lu}_{16}=\mathrm{L}$ & $\mathrm{u}_{13}=\mathrm{Pu}_{15}=\mathrm{Pu}_{16}=\mathrm{P}$ & $\mathrm{u}_{13}=\mathrm{Cu}_{15}=\mathrm{Pu}_{16}=\mathrm{C}$ & $\mathrm{u}_{13}=\mathrm{Cu}_{15}=\mathrm{Cu}_{16}=\mathrm{C}$ \\
\hline $\mathrm{BR}_{16}$ & $\mathrm{O}_{16}$ & $\mathrm{u}_{15}=\mathrm{Lu}_{16}=\mathrm{L}$ & $\mathrm{u}_{15}=\mathrm{Pu}_{16}=\mathrm{P}$ & $\mathrm{u}_{15}=\mathrm{Pu}_{16}=\mathrm{C}$ & $\mathrm{u}_{15}=\mathrm{Cu}_{16}=\mathrm{C}$ \\
\hline $\mathrm{BR}_{17}$ & $\mathrm{O}_{17}$ & $\mathrm{u}_{12}=\mathrm{Lu}_{16}=\mathrm{L}$ & $\mathrm{u}_{12}=\mathrm{Pu}_{16}=\mathrm{P}$ & $\mathrm{u}_{12}=\mathrm{Cu}_{16}=\mathrm{P}$ & $\mathrm{u}_{12}=\mathrm{Cu}_{16}=\mathrm{C}$ \\
\hline $\mathrm{BR}_{18}$ & $\mathrm{O}_{18}$ & $\mathrm{u}_{11}=\mathrm{Lu}_{16}=\mathrm{L}$ & $\mathrm{u}_{11}=\mathrm{Pu}_{16}=\mathrm{P}$ & $\mathrm{u}_{11}=\mathrm{Cu}_{16}=\mathrm{P}$ & $\mathrm{u}_{11}=\mathrm{Cu}_{16}=\mathrm{C}$ \\
\hline $\mathrm{BR}_{19}$ & $\mathrm{O}_{19}$ & $\mathrm{u}_{14}=\mathrm{Lu}_{16}=\mathrm{L}$ & $\mathrm{u}_{14}=\mathrm{Pu}_{16}=\mathrm{P}$ & $\mathrm{u}_{14}=\mathrm{Cu}_{16}=\mathrm{P}$ & $\mathrm{u}_{14}=\mathrm{Cu}_{16}=\mathrm{C}$ \\
\hline \multicolumn{6}{|c|}{ Level 2 - the system of UPPT } \\
\hline $\mathrm{BR}_{21}$ & $\mathrm{O}_{21}$ & $\mathrm{u}_{21}=\mathrm{Lu}_{22}=\mathrm{Lu}_{23}=\mathrm{Pu}_{24}=\mathrm{P}$ & $\mathrm{u}_{21}=\mathrm{Lu}_{\mathrm{h}_{2}}=\mathrm{Pu}_{\mathrm{V}_{3}}=\mathrm{Cu}_{\mathrm{u}_{4}}=\mathrm{P}$ & $\mathrm{u}_{2}=\mathrm{P}\left(\mathrm{u}_{21}=\mathrm{Pu}_{23}=\mathrm{Gu}_{24}=\mathrm{C}\right)$ & 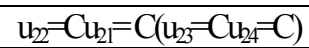 \\
\hline $\mathrm{BR}_{22}$ & $\mathrm{O}_{22}$ & $\mathrm{u}_{23}=\mathrm{Lu}_{27}=\mathrm{L}$ & $\mathrm{u}_{23}=\mathrm{Pu}_{27}=\mathrm{P}$ & $\mathrm{u}_{23}=\mathrm{Cu}_{27}=\mathrm{P}$ & $\mathrm{u}_{23}=\mathrm{Cu}_{27}=\mathrm{C}$ \\
\hline $\mathrm{BR}_{23}$ & $\mathrm{O}_{23}$ & $\mathrm{u}_{23}=\mathrm{Lu}_{26}=\mathrm{Lu}_{27}=\mathrm{L}$ & $\mathrm{u}_{23}=\mathrm{Pu}_{26}=\mathrm{Lu}_{27}=\mathrm{P}$ & $\mathrm{u}_{23}=\mathrm{Cu}_{26}=\mathrm{Pu}_{27}=\mathrm{C}$ & $\mathrm{u}_{23}=\mathrm{Cu}_{26}=\mathrm{Cu}_{27}=\mathrm{C}$ \\
\hline $\mathrm{BR}_{24}$ & $\mathrm{O}_{24}$ & $\mathrm{u}_{23}=\mathrm{Lu}_{28}=\mathrm{Lu}_{29}=\mathrm{L}$ & $\mathrm{u}_{23}=\mathrm{Lu}_{28}=\mathrm{Pu}_{29}=\mathrm{P}$ & $\mathrm{u}_{23}=\mathrm{Pu}_{28}=\mathrm{Cu}_{29}=\mathrm{C}$ & $\mathrm{u}_{23}=\mathrm{Cu}_{28}=\mathrm{Cu}_{29}=\mathrm{C}$ \\
\hline $\mathrm{BR}_{25}$ & $\mathrm{O}_{25}$ & $\mathrm{u}_{25}=\mathrm{Lu}_{27}=\mathrm{L}$ & $\mathrm{u}_{25}=\mathrm{Lu}_{27}=\mathrm{P}$ & $\mathrm{u}_{25}=\mathrm{Pu}_{27}=\mathrm{C}$ & $\mathrm{u}_{25}=\mathrm{Cu}_{27}=\mathrm{C}$ \\
\hline $\mathrm{BR}_{26}$ & $\mathrm{O}_{26}$ & $\mathrm{u}_{27}=\mathrm{Lu}_{28}=\mathrm{Lu}_{29}=\mathrm{L}$ & $\mathrm{u}_{27}=\mathrm{Pu}_{28}=\mathrm{Lu}_{29}=\mathrm{P}$ & $\mathrm{u}_{27}=\mathrm{Cu}_{28}=\mathrm{Pu}_{29}=\mathrm{C}$ & $\mathrm{u}_{27}=\mathrm{C}\left(\mathrm{u}_{28}=\mathrm{Cu}_{29}==\mathrm{C}\right)$ \\
\hline \multicolumn{6}{|c|}{ Level 3 - the municipal transport system } \\
\hline $\mathrm{BR}_{31}$ & $\mathrm{O}_{31}$ & $\mathrm{u}_{31}=\mathrm{Lu}_{32}=\mathrm{Lu}_{34}=\mathrm{L}$ & $\mathrm{u}_{31}=\mathrm{Pu}_{32}=\mathrm{Pu}_{34}=\mathrm{P}$ & $\mathrm{u}_{31}=\mathrm{Pu}_{32}=\mathrm{Cu}_{34}=\mathrm{P}$ & $\mathrm{u}_{31}=\mathrm{Cu}_{32}=\mathrm{Cu}_{34}=\mathrm{C}$ \\
\hline $\mathrm{BR}_{32}$ & $\mathrm{O}_{32}$ & $\mathrm{u}_{32}=\mathrm{Lu}_{33}=\mathrm{Lu}_{35}=\mathrm{L}$ & $\mathrm{u}_{32}=\mathrm{Pu}_{33}=\mathrm{Pu}_{35}=\mathrm{P}$ & $\mathrm{u}_{32}=\mathrm{Pu}_{33}=\mathrm{Cu}_{35}=\mathrm{P}$ & $\mathrm{u}_{32}=\mathrm{Cu}_{33}=\mathrm{Cu}_{35}=\mathrm{C}$ \\
\hline $\mathrm{BR}_{33}$ & $\mathrm{O}_{33}$ & $\begin{aligned} \mathrm{u}_{33} & =\mathrm{Lu}_{34}=\mathrm{Lu}_{35}= \\
& =\mathrm{Lu}_{36}=\mathrm{L}\end{aligned}$ & $\begin{aligned} \mathrm{u}_{33} & =\mathrm{Pu}_{34}=\mathrm{Pu}_{35}= \\
& =\mathrm{Pu}_{36}=\mathrm{P}\end{aligned}$ & $\begin{aligned} \mathrm{u}_{33} & =\mathrm{Cu}_{34}=\mathrm{Pu}_{35}= \\
& =\mathrm{Pu}_{36}=\mathrm{C}\end{aligned}$ & $\begin{aligned} \mathrm{u}_{33} & =\mathrm{Cu}_{34}=\mathrm{Cu}_{35}= \\
& =\mathrm{Cu}_{36}=\mathrm{C}\end{aligned}$ \\
\hline $\mathrm{BR}_{34}$ & $\mathrm{O}_{34}$ & $\mathrm{u}_{32}=\mathrm{Lu}_{36}=\mathrm{L}$ & $\mathrm{u}_{32}=\mathrm{Pu}_{36}=\mathrm{P}$ & $\mathrm{u}_{32}=\mathrm{Pu}_{36}=\mathrm{C}$ & $\mathrm{u}_{32}=\mathrm{C} \vee \mathrm{u}_{36}=\mathrm{C}$ \\
\hline \multicolumn{6}{|c|}{ Level 4 - meta-system } \\
\hline $\mathrm{BR}_{41}$ & $\mathrm{O}_{41}$ & $\begin{aligned} \mathrm{u}_{41} & =\mathrm{Lu}_{42}=\mathrm{Lu}_{43}= \\
& =\mathrm{Lu}_{44}=\mathrm{L}\end{aligned}$ & $\begin{aligned} \mathrm{u}_{41} & =\mathrm{Pu}_{42}=\mathrm{Pu}_{43}= \\
& =\mathrm{Pu}_{44}=\mathrm{P}\end{aligned}$ & $\begin{aligned} \mathrm{u}_{41}=\mathrm{Cu}_{42}=\mathrm{Cu}_{43}= \\
=\mathrm{Pu}_{44}=\mathrm{C}\end{aligned}$ & $\begin{aligned}\left(\mathrm{u}_{41}\right. & =\mathrm{Cu}_{42}=\mathrm{Cu}_{43}= \\
& =\mathrm{C}) \mathrm{u}_{44}=\mathrm{C}\end{aligned}$ \\
\hline
\end{tabular}

The inter-level transition between the risk factors and their indicators in the given model are implemented by mapping the linguistic variables

$$
o_{k i}=u_{(k+1) i}, i=\overline{1, n} \text {, }
$$

where $k$ is the methodological level of UPPT performance.

Critical assessment of the indicator of the level of risk $k$ regardless of the condition factors of the level $(k+1)$ involves the provision of assessment of risk indicators at a critical level. under the appropriate conditions of manufacturing processes can be compensated by internal UPPT resource reserves. The second group of formed rules reflects a state in which there is a transition in the zone of unacceptable risks. This condition leads to leaving it outside of the acceptable level of service-resource settings. The fuzzy production rules of forming the risk assessment of UPPT sustainability are shown in table 2. 
ble to estimate the priorities of risks (low, middle, high, critical) and to determine the character of their influence on the state of the ME. The procedure of fuzzification of factors and indexes of the risk of UPPT constancy is conducted on the basis of determining the functions of belonging of great numbers of terms of entrance and exit values and needs implementation of researches in the area of forming their criticality in relation to the purpose of the ME metasystem.

\section{Conclusion}

The presented fuzzy production model of risk assessment of UPPT sustainability is based on the implementation of the procedures for determining the rules of the state of transition of the internal and external level. The necessary condition for the implementation of this procedure is the selection of membership functions of fuzzy sets which characterize the risk factors. The presented terms for their estimation have threelevel forms that require the selection of limits of determination of their belongings. The task of determination of limits of belonging of fuzzy sets consists in the selection of the kind and the character of function and parametrization of its key transit points. In a general view of terms they use piecewise linear functions of belonging for the offered form. The factor, which determines the degree of belonging of an element to the appropriate term, is the level of reserves of resource capabilities.

\section{References}

1. Redman L., Friman M., Gärling T., Hartig T. Quality attributes of public transport that attract car users: A research review / L. Redman, M. Friman, T. Gärling, T. Hartig // Transport Policy. - 2013. - №25. P. 119-127.

2. Бобылев С.Н. Индикаторы устойчивого развития для городов / С.Н. Бобылев, О.В. Кудрявцева, С.В. Соловьева // Экономика региона. - 2014. - №3. - С. 101109.

3. Dobranskyte-Niskota A. Indicators to assess sustainability of transport activities / A. Dobranskyte-Niskota, A. Perujo, M. Pregl // Joint Research Centre. - 2007. -60 p.

4. Eboli L. Performance indicators for an objective measure of public transport service quality / L. Eboli, G. Mazzulla // European Transport. - 2012. - Issue 51(3). - P. 1-21.
5. Mihyeon J.C. Addressing sustainability in transportation systems: definitions, indicators, and metrics / J.C. Mihyeon, A. Amekudzi // Journal of infrastructure systems. 2005. - №1. - P. 31-50.

6. Samchuk G. Using sustainable development principles to assess the efficiency of transport interchanges functioning / G. Samchuk // Автомобильный транспорт: сб. науч. тр. -2016. - Вып. 38. P. 13-20.

7. Black J.A. Sustainable urban transportation: performance indicators and some analytical approaches / J.A. Black, A. Paez, P.A. Suthanaya // Journal of urban plan ning and development. - 2002. - №4. P. 184-209.

\section{References}

1. Redman L., Friman M., Gärling T., Hartig T. Quality attributes of public transport that attract car users: A research review. Transport Policy. 2013. no. 25. pp. 119-127.

2. Bobyilev S.N., Kudryavtseva O.V., Soloveva S.V. Indikatoryi ustoychivogo razvitiya dlya gorodov [Indicators of sustainable development for cities]. Ekonomika regiona. 2014. no. 3. pp. 101-109.

3. Dobranskyte-Niskota A., Perujo A., Pregl M. Indicators to assess sustainability of transport activities. Joint Research Centre. 2007. $60 \mathrm{p}$.

4. Eboli L., Mazzulla G. Performance indicators for an objective measure of public transport service quality. European Transport. 2012. Issue 51(3). pp. 1-21.

5. Mihyeon J.C., Amekudzi A. Addressing sustainability in transportation systems: definitions, indicators, and metrics. Journal of infrastructure systems. 2005. no. 1. pp. $31-50$.

6. Samchuk G., Using sustainable development principles to assess the efficiency of transport interchanges functioning. Avtomobilnyiy transport. 2016. vol. 38. pp. 13-20.

7. Black J.A., Paez A., Suthanaya P.A. Sustainable urban transportation: performance indicators and some analytical approaches. Journal of urban planning and development. 2002. no. 4. pp. 184-209.

Рецензент: Є.В. Нагорний, професор, д.т.н., ХНАДУ. 